\title{
Challenges Faced by Distance Education Students of the University of Education, Winneba: Implications for Strategic Planning
}

\author{
J. B. Ohene (Corresponding author) \\ University of Education, Winneba, Ghana \\ E-mail: Julieboato@gmail.com \\ S. O. Essuman \\ University of Education, Winneba, Ghana \\ E-mail: sessuman@uew.edu.gh
}

Received: February 11, 2014 Accepted: February 25, 2014 Published: May 19, 2014

doi:10.5296/jet.v1i2.5669 URL: http://dx.doi.org/10.5296/jet.v1i2.5669

\begin{abstract}
Over a decade now, Distance Education (DE) has become ubiquitous in the Ghanaian educational system. Four public universities in Ghana are currently running DE programmes in addition to a few private universities. Effective DE programme demands that strategic planning be made at all times. Such planning could be done well if challenges confronting learners on the programme are identified and addressed. This paper sets out to explore and provide an up-to-date picture of the challenges faced by DE students in their quest to study at the university level. Specifically, the study focused on students of the University of Education, Winneba (UEW) as a case study. UEW is one of the nine public universities in Ghana which has been involved in distance education for teachers at the pre-tertiary level. The study adopted both qualitative and quantitative research designs with interviews and questionnaire as the data collection techniques. One hundred and fifty-six students comprising sixty-eight males and eighty-eight females responses out of initial three hundred were received which is equivalent to a response rate of $52 \%$. This constitutes the sample size for the study. Among the challenges identified were - institutional, instructional, social, psychological, and financial. The findings of the study, it is expected, will be utilized instrumentally and conceptually in informing policy directives by public universities presently involved in DE programmes. Further, private and potential providers of DE programme in the country stand
\end{abstract}


to gain a lot from the findings and recommendations of the study.

Keywords: Distance Education, barriers to DE students/learners, institutional and psychological barriers

\section{Introduction}

Ghanaian universities have been involved in D.E. for some time now. Distance Education programmes are currently being pursued by four of the nine public Universities in Ghana. These are the University of Education, Winneba (UEW), University of Cape Coast UCC), Kwame Nkrumah University of Science and Technology (KNUST) and the University of Ghana (UG). The approaches, programmes and students demographics differ from institution to institution. The various institutions use the term distance education and distance learning interchangeably so also will this article do.

This paper explores the challenges faced by distance education students in their quest to study in the university. Specifically, the study focuses on public Universities in Ghana. While drawing on experiences from the University of Education, Winneba, references would be made to other studies done elsewhere. In this study, emphasis is placed on the following; challenges that pertain to individuals' situation, challenges relating to institutional set-up, financial challenges and few others.

There has been scanty research in Ghana into tertiary level distance education especially about challenges students face as well as its trajectories since the programmes are relatively new. Distance Education programme in Ghana is being pursued as a means of expanding higher education opportunities and more importantly improving the academic standing of most in-service teachers. Thus, teachers constitute the majority of the distance education students, particularly on the University of Education, Winneba (UEW) programme. Students pursuing this programme however face numerous challenges ranging from institutional, social to personal. To enable the institution plan effectively to sustain the students on the programme and also to reduce the burden on the students, these challenges ought to be known and addressed.

The purpose of this study therefore is to explore the challenges faced by DE students. It is hoped that the findings of the study will be utilized instrumentally and conceptually in informing policy directives by the university and perhaps by others equally involved in similar DE programmes. This study also aims to find out how distance education students try to manage their multiple roles and learning. As distance education has now become a fact of life for most universities in the country, it will be appropriate for policy decisions regarding DE implementation to be premised upon knowledge about the intrinsic and extrinsic problems facing the students. Investigating the challenges facing the students will therefore enable DE educators to improve upon their skills and styles of teaching to help mitigate them.

Institutions running DE programmes in Ghana face the challenge of serving student population which is diverse in terms in enrollment, demography, location and level of advanced knowledge prior to enrollment into programmes. Currently, DE students are the fastest growing segment of tertiary education in the country. In the University of Education, 
Winneba and the University of Cape Coast, DE students constitute the majority of students.

Students, who enroll on distance education programmes, it is believed, do so for several reasons, including convenience. Distance education students who are mainly adult workers may be time-bound due to work or location-bound due to geographic or family responsibilities (Galusha, 2012). A special case of Ghana is that of policy change or pressure to improve qualification from employer, an unusual case of Ghanaian teachers. Thus, knowing the characteristics and demographics of the students will help the organizers or institutions to understand the challenges. Further, understanding the students and the challenges they face could provide insights for planning, course development and policy formulation.

\subsection{Objectives}

The main objectives of the study are to:

1. Explore the different problems such as institutional, instructional, social, psychological and financial that confront distance education students of the University of Education, Winneba

2. Advance some possible solutions to address the challenges confronting DE students of the university

\subsection{Research Questions}

Research questions guiding the study are:

1. What are the possible institutional and instructional problems that confront DE students of the University of Education, Winneba?

2. What social, psychological and financial problems pose as challenges to DE students of the University of Education, Winneba?

3. What possible solutions could be advanced to address challenges confronting DE students of the University of Education, Winneba?

\section{Literature Review}

\subsection{Definition of the Term Distance Education}

According to Eastmond (1995, as cited by Kerka 1996:98), some define distance education as the use of print or electronic communications media to deliver instruction when teachers and learners are separated in place and/or time. However, others emphasize distance learning over education, defining it as "getting people - and often video images of people - into the same electronic space so they can help one another learn" (Filipczak, 1995:111) or "a system and process that connects learners with distributed resources". The Commonwealth of Learning defines distance education as that which refers to situations where learners are physically separated from the educational provider, communicating in writing, (using letter, mail, email, fax or computer conferencing; verbally (by telephone, audio conferencing, video conferencing); or in face-to-face tutorial sessions' (COL, 2003 pp.13). What can be gathered from these definitions is that distance education or learning is an approach used by providers of education for students who study when and where it suits them best. There is continuous 
learning by students in this mode of education, which usually suits students who fulfill other commitments such as work, family and community.

Typically in the past, audiences for distance education opportunities were adults often seeking advanced education and training at home, on the job, or in the military. Their multiple responsibilities or physical circumstances prevented attendance at a traditional institution (Bates, 1995 cited by Kerka, 1996:98). But presently, anyone is potentially a distance learner, a concept that has implications for Africa. The literature on distance education in Ghanaian universities is limited though there are extensive literature from other parts of Africa, especially east and south where distance education started long ago. Most literature and policy discourses in distance education often prioritise on expanding access to the disadvantage of challenges experienced by students admitted. A number of challenges to distance learning have been identified in the literature. The literature appears to have classified the challenges encountered by distance students into several categories; institutional barriers, level of education prior to joining DE, financial, and support services.

It has been argued that distance learners' behavior is influenced by a combination of factors including their needs, characteristics and situation (Knowles, 1980). Writing about challenges for distance learning, policy and practice, Moodley (2002) argues about the negative attitudes to and stereotyping difference to distance learning to include: an inflexible curriculum, in accessible learning materials, socio-economic barriers, poverty and underdevelopment and factors which place the learner at risk. He continues to argue that:

Effective learning is directly related to and dependent on the social and emotional well being of the learner. It is important to recognise that particular conditions may arise within the social, economic and political environment in which the learner lives, and which impact negatively on the learner's social and emotional well-being, thus placing the learner at risk of learning breakdown. Such factors either influence learners or their family or community directly (Moodley, 2002).

Galusha cited in Dabaj (2011), propounds that there are many barriers in teaching and learning process of distance education. He argues that the most common being the unawareness of the roles as teachers and students. Further he asserts that studies show that the barriers of distance education fall into such categories as cost, motivators, feedback and teacher contact, student support and services, alienation, lack of experience and training. In addition, course content on the other hand constitutes another barrier and should be modified in distance education (ibid). Therefore, to create effective and qualified distance education all barriers must be identified and eliminated. But it is worth noting that these challenges usually overlap and merge together at some point.

Again, Lehman (1998) writing about barriers to distance education, categorizes the teacher related barriers as philosophical, logistical, administrative, technological [including existing telecommunication systems, ergonomic concerns and lack of funds for new devices]; and the student related barriers as lack of interaction (i.e. feedback) with instructor and classmates, lack of support services, resistance to change and lack of training in technical issues. He argues that many students, like the faculty, are used to and are comfortable with traditional 
classroom education; and that:

Distance education has failed to become integrated into the academic culture, not as a result of the commonly cited factors of cost and faculty resistance, but rather due to the insistence of distance educators on perpetuating a culture that is out of touch with the driving force of higher education (Lehman, 1998).

What can be gathered from these barriers is that situational barriers are persistent and pertain to the individual's particular situation. Thus, the ability to handle these situational barriers will determine ones participation in distance programmes. The individual's situational barrier may refer to his or her responsibilities at home, place of work or community. Many distance learners are within the working class bracket and are married adult learners taking care of the family. Therefore, they need to possess the ability to balance their time for the different roles and responsibilities.

Galusha (2012) also asserts that students' age, type of work and marital status constitute an important aspect of situational barrier. Lack of adequate money to cover the cost of the programme constitutes yet another aspect of situational barrier and the financial barrier. The level of one's salary, access to loan and the desire to improve one's self for a better future may determine the urge to go for a loan to pursue further education.

Institutional barriers are those barriers caused by organisational set-up. These barriers may be both physical and non-physical. The physical barriers may include such things as nearness to classroom, road net-work and other academic resources such as the library. Stringent admission requirements, high tuition fees and the mode of paying these fees constitute some of the non-physical barriers. Other barriers, which come under this category, are non-interesting courses, inadequate text-books, poor library facilities and poor organization of class and examination (Cross, 1981).

Keegan (1986) and Tinto (1975) believe that the lack of feedback on performance or contact with teachers also constitute a barrier to distance students. Keegan (1986) argues that the link between the teacher and the student constitutes a vital link in teaching-learning transaction and that the link, which is broken by distance, must be restored one way or the other. This particular barrier creates the problem of evaluation for the student. It is suggested that the barrier created by the absence of a teacher could be mitigated through technological methods. However, Braimoh and Osiki (2008) raise concern about this approach of restoring the teaching learning transaction in Africa because of the low development of the ICT sector. It is further argued that the use of ICT in distance education poses a lot of challenges due to uneven and unequal access to computers and the internet and most importantly the fact that power supply is unstable.

Another set of barriers, which constitute a challenge are the issues of 'distance' and the perception of alienation. According to Galusha (2012, p.4) and I share this view, "Students of all kinds want to be part of a larger school community". For both traditional and distance students, being part of that community is an important part of their social lives. As part of institutional arrangements, Universities tend to separate regular traditional students from 
distance students during official activities such as matriculation and congregation.

The lack of support and service to distance students also constitute a major barrier. Learner support generally refers to interactive activities and services that are meant to support and facilitate the learning process. As already indicated support is essential because of the separation between the learner and the educational provider. Broadly, such services include teaching, tutoring, counselling, advising and administrative services. Simpson (2003) considered learner support services as being measures that go beyond the production of study materials and support the learning process. He further identified and differentiated between academic and non-academic support.

Support and services required by distance students are in the form of social and technology. The fact that the bulk of distance education students are workers from the various sectors and regions of the country, which are in different levels of development in terms of infrastructure, makes the challenges and solutions varied.

\section{Methodology}

An exploratory research design using mixed methods of survey and interviews was adopted for the study. This is because the aim of the study was to explore the challenges facing most students on the distance education programme and to recommend ways to reduce them. Distance education students of UEW are spread throughout the ten regions of the country. However, the study area was located in the southern sector, namely, Cape Coast, Koforidua and Winneba. These are the three largest centres in the southern sector and were selected for easy accessibility as well as due to the time constraint. Both random and purposive sampling techniques were used in sampling 300 students [100 from each of the three study centres] and 9 student leaders, 3 from each of the three centres] respectively. The student leaders were purposively sampled because they were considered to be 'information-rich' respondents. Their responses were to be used to triangulate responses from the survey. It needs to be mentioned that the findings would be more applicable to students from these three centres. However, other centres with similar characteristics of students may find the data relevant and valid to their students.

The survey questionnaire and the semi-structured interview guide were piloted on four students and one student leader to establish the reliability of the instruments. The research questions served as a guide in designing the two instruments. Piloting the instruments was to correct any ambiguity of the questions. From this, the final survey questionnaire and interview guides were developed.

The selection of the students for the survey was by stratified random sampling (Cohen et.al., 2000); Characteristics considered for stratification were gender, year on the programme (Post Diploma $1 \&$ Post Diploma 2 students) and the elective subject groups of the students. Since the elective subjects groups consisted of sizeable numbers, equal number of males and females were selected in Post Diploma 1 and Post Diploma 2 to a total of 100 students from each centre. The questionnaires were distributed to them for completion and they were to return them after a week during their next tutorial session. It needs to be mentioned that after the period, 156 out of the 300 students completed and returned their questionnaires, making 
the return rate to be $52 \%$.

With the interview, student leaders were purposively sampled from the three centres and from Post Diploma 2 (year 2). This is because it was considered that after two years on the programme, these leaders, who are the spokespersons of the students possess 'rich information' of complaints and grievances of students and would be in a better position to voice them out. In other words, they were the 'typicality' (Cohen et. al. 2000) of the student body. Interviewees were assured of confidentiality, anonymity, as pseudonyms would be used in the write up and sought their voluntary consent. Interview day, time and venue were agreed and scheduled with individual student leaders at the three centres. A day each was allocated to each centre and each interviewee was engaged for a period of 20 minutes. All interviewees were punctual on their scheduled days and times for the interview. A semi-structured interview guide, which gave room for probing questions to be asked was used. The interviews were audio recorded with the permission of interviewees. These were transcribed from audio to text and used for the analysis. To guard against bias and to avoid any influence on the data, interviewees were urged to be honest and objective as much as possible. The interviewer also comported herself to stay disinterested in responses given by interviewees. These measures contributed to the validity of the data collected. Further, the careful sampling of respondents, using audio-recorder to record, store and retrieve data and the appropriate instruments used for both the survey and the interview ensured internal and content validity.

The statistical package for social science research (SPSS) was used in analysing the questionnaire data whilst the interview data were analysed manually using inductive and thematic analyses. In this regard, responses from the same question number on the interview guide were grouped together and read over several times to extra meanings and themes from the responses. Data from the analysis of the questionnaire were corroborated with data from the interviews.

\section{Analysis and Discussion of Findings}

The core issue in this paper is that distance education students on UEW Basic Education programme face various challenges as they embark of their programmes. As such the survey questionnaire and the interviews were to explore these factors and propose suggestions for minimizing these problems. The thematic approach was used in the analysis of the data. The findings that emerged from the data centre on lack of institutional, psychological, social, financial and instructional support. It is worth noting that some responses cut across some themes and these were discussed under one theme.

The bio data of the sample indicate that $83.3 \%$ (130) of respondents are within the age range of 29-39 with female students numbering more (73) than male students (57). This finding is consistent with the basic statistics (male-661/female-1,045) (University of Education, Winneba, 2013). The female population often out-number the male population on DE programmes. This high female population on DE programmes may be understood from the unique mode of delivery, which fits females with their multiple roles as career and family women and at the same time have to upgrade themselves. 


\subsection{Institutional Support}

On the issue of institutional support and whether there are structures in place to support teaching and learning, Figure 1 depicts the graph of students' responses. From the figure, majority of the respondents strongly agree and agree that there are good structures in place to support the DE programmes as well as the positive direction and support of the university towards the programmes. In that regard; $62.2 \%$ strongly agree and agree, whilst $23.1 \%$ disagree, $14.7 \%$ were undecided. It could be gathered from the undecided and disagree categories that they might be comparing the support given to regular students to that of DE which is usually not very clear. Institutional support in this context refers to the counselling services, study centre locations and learning facilities available at those centres. On campus, regular students seem to have all that they need for their studies around them whilst DE students would have to travel to access them.

Table 1. Positive institutional support

\begin{tabular}{|l|c|c|}
\hline & Frequency & Percent \\
\hline Strongly Agree & 15 & 9.6 \\
\hline Agree & 82 & 52.6 \\
\hline Undecided & 23 & 14.7 \\
\hline Strongly Disagree & 14 & 9.0 \\
\hline Disagree & 22 & 14.1 \\
\hline Total & 156 & 100.0 \\
\hline
\end{tabular}

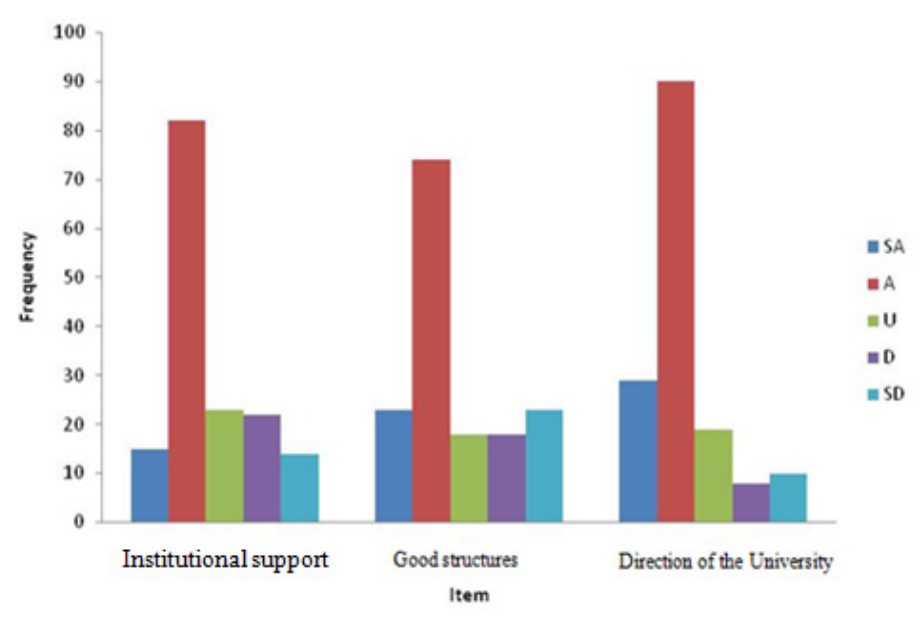

Figure 1. Graphical representation of responses to:

(i) Institutional support (Table 1, see Appendix)

(ii) Good structures in place (Table 2, see Appendix)

(iii) Appreciation of the University (Table 3, see Appendix)

Respondents that disagree to the institutional support could be arguing from the angle some interviewees talked about concerning the late release of quiz and examination results. This was considered as problematic as students who had to re-sit examinations do not get to know 
early enough to prepare for them. The late release poses challenge to their early completion of their programmes to graduate. In the same vein, they raised concern about the short duration and time allocated for tutorials. This is because they travel from far to the study centre for the tutorials and would wish to close early to enable them get back to their destination early enough to prepare for the following week's activities.

Tutorial duration is from (8:00am to 4:30pm), and that's too long, therefore it makes us close late making it difficult to get back home on time. [Student leader]

We receive our quiz results very late making us make the same mistakes in the end of semester examinations if that question is repeated. . [Student leader]

\subsection{Instructional Challenge to DE Students}

On the questionnaire and during the interview students were asked to share their opinion on instructional challenge that they have. The responses indicate that most of them (7 out of 9) had issue with various aspects of instruction. For instance, two interviewees commented that:

Instructional materials come to students late; in some cases we do not get the books at all. Due to this we have to make photocopies meanwhile we have paid our fees. [Student Leader]

Most students complain bitterly when they are asked to consult tutors and collect their modules for photocopy. Their complains are that when modules or books are in the manuscript form they look voluminous and difficult to photocopy the document and even read and on top of that they have no money to do the copying. [Student leader 4]

These concerns are genuine since under the normal circumstance, all course books for a particular level are supposed to be given out to students at the beginning of the semester. Any delay therefore poses inconvenience. However, there were positive responses about the instructional aspect of the programme such as in Figure 2

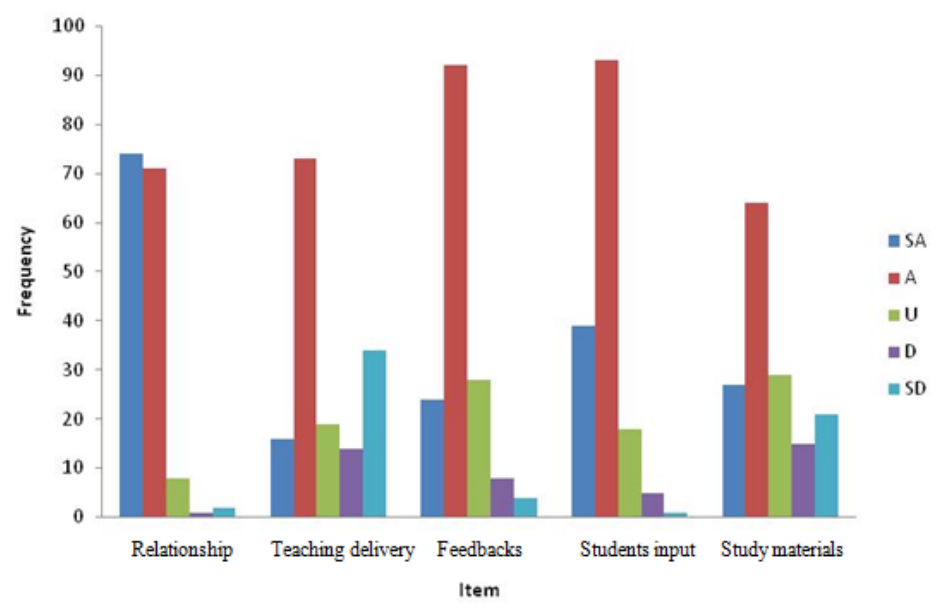

Figure 2. Graphical representation of responses to:

(i) Relationship (Table 4, see Appendix) 
(ii) Teaching delivery (Table 5, see Appendix)

(iii) Feedbacks (Table 6, see Appendix)

(iv) Students input (Table 7, see Appendix)

(v) Study Material (Table 8, see Appendix)

Almost all respondents appreciated the cordial relationship that exists between tutors and students during tutorial sessions. Also, majority agree that learning materials have been designed in a learner-friendly manner, thereby making it easy to read and understand. Respondents also indicated that lecturers give constructive feedback to them, which encourages them to stay focused. In addition, lecturers tolerate their inputs in class and this helps to boost their confidence. This confirms Lehman (1998), Keegan (1986) and Tinto's (1975) view that lack of feedback on performance from teachers constitutes a barrier to distance students, and that the link between the teacher and the student constitute a vital link in any teaching-learning transaction, which must not be broken especially in the DE context.

\subsection{Financial Challenge}

On the issue of financial challenges, most respondents expressed their views in various ways as indicated in Figure 3.

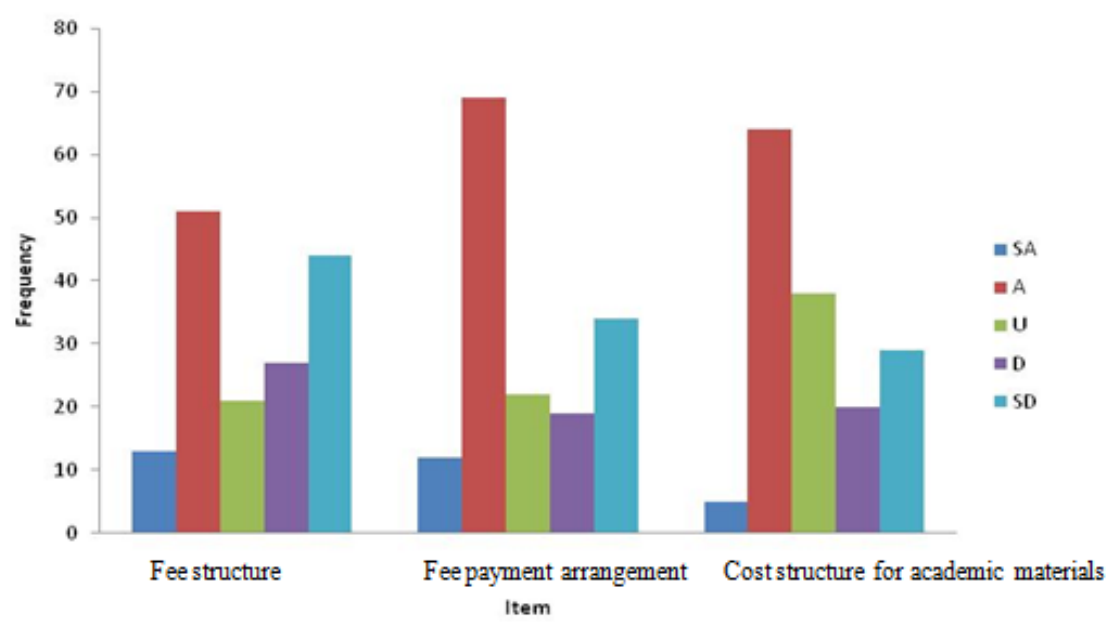

Figure 3. Graphical representation of responses to:

(i) Fee structure (Table 9, see Appendix)

(ii) Fee paying arrangement (Table 10, see Appendix)

(iii) Cost structure for Academic materials (Table 11, see Appendix)

From the data, about 41\% (64 out of 156) strongly agree and agree that the way the fees have been structured for them is acceptable; whilst $45.5 \%$ (71 out of 156) disagree and strongly disagree to the fee structure. $13.5 \%$ that is 21 out of the 156 were undecided about the arrangement. In a similar manner, the analysis for the cost structure for the academic materials, that is, the course books indicates that $44.2 \%$ (69 out of 156) agree whilst $31.4 \%$ (49 out of 156) disagree with the arrangement. This seems to be 50:50 agreeing to disagreeing; which means that the arrangements are not favourable to most students. This is not surprising since most DE students happen to be workers and have diverse commitments 
to meet. Galusha (2012) argues that most DE students have age, type of work and marital status commitment to deal with and lack adequate money to cover the cost of their programmes, which constitutes an aspect of situational and financial barrier. Most students are not also at a level that they can access loans to upgrade themselves. This forms part of the basis for accepting the fee payment structure arrangement by the university. One interviewee commented that:

Students genuinely have financial problems. A number of my colleagues have come to complain about their fees and even money for transport to tutorials is a problem to them. One class prefect once said he has not paid his fees because he has to pay his children's fees first. [Student leader]

\subsection{Psychological challenge to DE students}

On the issue of psychological barriers that distance education students face, factors that respondents commented on included, the conducive academic atmosphere for learning, academic counselling unit, available avenues for students to report and effective non-academic counselling unit. From Figure 4 and Table 2 most respondents, 68\% (106 out of 156) were of the view that there is a favourable academic atmosphere for learning.

However, on the issue of effective counselling unit in place to support students' academic work, most respondents 92 out of a total of $156(58.9 \%)$ strongly disagreed with the statement. If the undecided group is added to those who disagreed, then almost $79.4 \%$ of the respondents are not in favour of that statement with only $20.6 \%$ agreeing according to Table 3.

Table 12. Conducive academic atmosphere for learning

\begin{tabular}{|l|l|l|}
\hline & Frequency & Percent \\
\hline Strongly Agree & 29 & 18.6 \\
\hline Agree & 77 & 49.4 \\
\hline Undecided & 16 & 10.3 \\
\hline Strongly Disagree & 17 & 10.9 \\
\hline Disagree & 17 & 10.9 \\
\hline Total & 156 & 100.0 \\
\hline
\end{tabular}

Table 15. Effective counselling unit to support students' academic work

\begin{tabular}{|l|c|c|}
\hline & Frequency & Percent \\
\hline Strongly Agree & 11 & 7.1 \\
\hline Agree & 21 & 13.5 \\
\hline Undecided & 32 & 20.5 \\
\hline Strongly Disagree & 62 & 39.7 \\
\hline Disagree & 30 & 19.2 \\
\hline Total & 156 & 100 \\
\hline
\end{tabular}



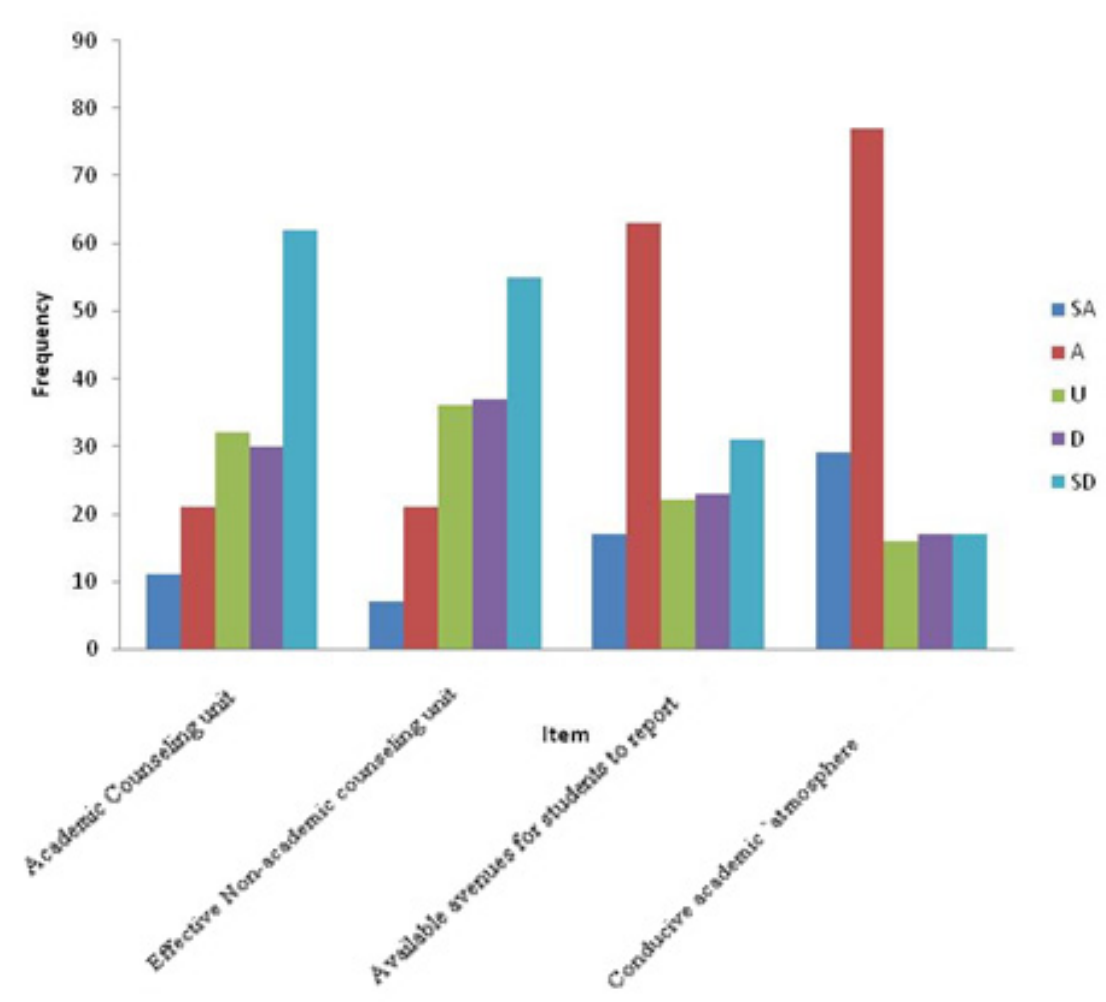

Figure 4. Graphical representation of responses to:

(i) Conducive Academic Atmosphere (Table 12, see Appendix)

(ii) Effective non-Academic Counselling Unit (Table 13, see Appendix)

(iii) Available avenue for students to report (Table 14, see Appendix)

(iv) Academic Counselling Unit (Table 15, see Appendix)

This indicates that most students' psychological needs are not being addressed. It is clear from the literature that many distance learners are working class students and at the same time taking care of their families. As such, balancing their time and other roles and responsibilities with the course work needs real support from providers. This is a comment from a student:

... My children disturb me a lot, therefore I find it difficult reading at home ...

Family responsibilities such as taking care of children and husband is my major problem ... [Student leader]

An effective unit where they could access counselling support will be desirable. It is worth noting that due to the distance between the tutor and the learner, there is the need to keep the line of communication and interaction always open. More importantly, learners' assignment feedback, other learning needs and motivation, all have to be addressed at this unit.

With learners being geographically distant from tutors, they are most times saddled with studying problems and need encouragement to meet their learning needs. 
Some students do not attach any seriousness to the programme. Thus I suggest tutor give intermittent guidance and motivation to students to make them sit up. [Student leader]

It needs to be mentioned that at some study centres, the facility is available but due to distance and lack of time, learners are unable to access the services. Similarly, staff at the facility centre who work for both regular and distance students do not show up on weekends that distance students attend tutorials. This calls for a better arrangement to be made for the use of the facility.

\subsection{Social Problems of Distant Learners}

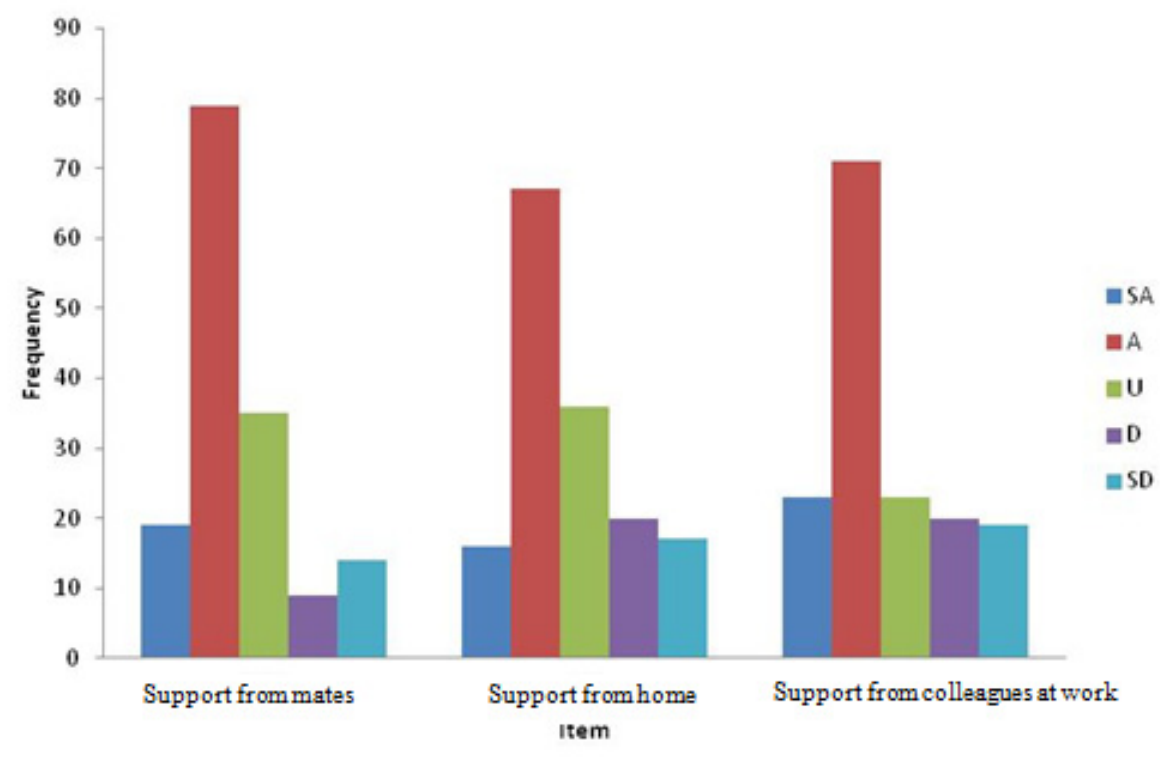

Figure 5. Graphical representation of responses to:

(i) Support from mates (Table 16, see Appendix)

(ii) Support from significant others and home (Table 17, see Appendix)

(iii) Support from colleagues at work (Table 18, see Appendix)

Table 18. Satisfied with informal support from colleagues

\begin{tabular}{|l|c|c|}
\hline & Frequency & Percent \\
\hline Strongly Agree & 19 & 12.2 \\
\hline Agree & 79 & 50.5 \\
\hline Undecided & 35 & 22.4 \\
\hline Strongly Disagree & 14 & 9.0 \\
\hline Disagree & 9 & 5.8 \\
\hline Total & 156 & 100.0 \\
\hline
\end{tabular}

In analyzing DE students' social problems it came to light that $62.7 \%$ of the respondents 
receive social support from their mates, for example meeting with their mates for group discussions and also calling their friends for further clarification on lectures and assignments, with only $14.8 \%$ indicating that they do not receive any support.

Table 5. Satisfied with support from significant others

\begin{tabular}{|l|c|c|}
\hline & Frequency & Percent \\
\hline Strongly Agree & 16 & 10.3 \\
\hline Agree & 67 & 42.9 \\
\hline Undecided & 36 & 23.1 \\
\hline Strongly Disagree & 17 & 10.9 \\
\hline Disagree & 20 & 12.8 \\
\hline Total & 156 & 100.0 \\
\hline
\end{tabular}

Considering the assistance students receive from others (peers, relations, etc) at home, 53.2\% of the respondents mentioned that they do receive needed support with as much as $23.1 \%$ undecided and $23.7 \%$ indicating that they do not receive any support.

A student mentioned that with the introduction of the tablet and the chip I have been chatting with my colleagues. This time if I am learning and I am not clear with something I just connect with a friend and we discuss.

\section{Conclusion and recommendations}

Distance Education is now gaining popularity in the country, (Ghana) however due to its numerous challenges it has not achieved the standard expected. The increasing demand for further studies as well as the high cost of regular education has made distance learning a popular choice for many especially the working population. Considering the demand for the Distance programme especially at UEW, it is believed that this study has confirmed most of the challenges listed in the literature as faced by Distance Students as well as uncovered a few that are peculiar to Distance Students of UEW. A particularly challenging situation is where registration is tied to full payment of fees.

These results are revealing. Institutional support, instructional challenges and financial challenges constitute the pillars of any distance education programme. Even though this study is quite an exploratory one the observations and results are real and need to be considered with all seriousness, especially the institutional/financial support. Also most importantly, even though results of the survey showed over 50\% agreeing with the prepositions, in absolute terms students not agreeing are large and the implications are varied. The inability of greater number of students to pay their fees could lead to poor management of structures, which raises questions on the sustainability of the programme. Considering the problems students encounter while on the programme, the findings seem to inform the policy makers to re-structure activities that would render quality education to the students. On the basis of the findings and the conclusion above, the following recommendations are worth considering: 


\section{Macrothink}

- There should be more flexibility in the payment of fees by DE students since they are adults and as such have to take care of their children and family members.

- The Government should provide DE students with the needed support as part of an effort geared towards the human capital development of the citizenry of Ghana. This is essential because DE students unlike others who come on study leave are expected to rely on student loan facilities to support their education since they are direct contributors to the system. Such a loan facility is inadequate since these students are adults and already have other responsibilities to render.

- There is the need to establish counseling centres in all the study centres and also employ professional counsellors to attend to the needs of the students.

- Counselling consists of one of the major non- academic support for Distance Education students where advising, exploring problems and offering directions take place. Since the University Counselling Centre staff do not come to work on Saturdays it is recommended that either the centre is open on Saturdays or basic training be given to the Study Centre Co-ordinators to offer those services.

- The UEW should institute a more elaborate study into the DE programme to fine-tune the entire programme to enhance its overall quality as leader of DE programme in Ghana.

\section{References}

Braimah \& Osiki, D. J. (2008). The Impact of Technology on Accessibility and Pedagogy; the Right to Education in Sub- Saharan Africa, Asian Journal of Distance Education, 6, 53-62.

Cross, K. P. (1981). Adults as learners; increasing participation and facilitating learning. California: Jossey Bass.

Dabaj, F. (2011). Analysis of Communication and Media Technologies. A Review Study,. Online Journal of Communication and Media Technologies, 6, 1-15.

Filipczak, B. (1995). Putting the Learning into distance education. Training, 32 (10), 111-118.

Galusha, J. M. (2012). Barriers to learning in Distance Education. Retrieved June 10, 2014, from http://www.infrastruction.com/barrier.htm

Keegan, D. (1986). The Foundations of Distance Education. London: Croom Helm.

Kerka, S. (1986). Distance learning, the Internet, and the world web. ERIC Digest, 96-168.

Knowles, M. (1980). The Modern Practice of Adult Education from Pedagogy to Andragogy. Chicago: Follet Publishers.

Lehman, D. (1998). Barriers to Distance Education, National Center for Educational Statistics (NCES). 1997. Statistical analysis report : distance education in higher education. Retrieved March 12, 2014, from http://nces.ed.gov/surveys/peqis/publications/9806

Mason, J. (2002). Qualitative Researching (2nd ed.). London: Sage.

Moodley, S. (2002). Pathways 6 Conference 2002 Inclusive Education; Challenges for Distance Learning, Policy and Practice, Academic Development Centre. Johannesburg, 
South Africa: Technikon.

Tinto, V. (1975). Dropout from higher education; a theoretical synthesis of recent research. Review of Educational Research, 45, 89- 125.

University of Education, Winneba. (2013). 17th Congregation Basic Statistics. Retrieved October 13, 2013, from http://www.uew.edu.gh

\section{Appendix}

(i) Questionnaire responses according to Study Centres

\begin{tabular}{|l|c|c|c|}
\hline Study Centres & \multicolumn{2}{|c|}{ No. of students responded } & Total \\
\hline & Male & Female & \\
\hline Cape Coast & 15 & 14 & 29 \\
\hline Koforidua & 14 & 17 & 31 \\
\hline Winneba & 39 & 57 & 96 \\
\hline Total & 68 & 88 & 156 \\
\hline
\end{tabular}

(ii) Student leaders interviewed

\begin{tabular}{|l|c|c|}
\hline Study Centres & Male & Female \\
\hline Cape Coast & 1 & 2 \\
\hline Koforidua & 1 & 2 \\
\hline Winneba & 1 & 2 \\
\hline Total & 3 & 6 \\
\hline
\end{tabular}

(iii) Tables 1-18:

$\underline{\text { Institutional Support }}$

Table 1. Positive Institutional Support

\begin{tabular}{|l|l|r|r|}
\hline & Frequency & \multicolumn{1}{|c|}{ Percent } \\
\hline \multirow{4}{*}{} & Strongly Agree & 15 & 9.6 \\
\cline { 2 - 4 } & Agree & 82 & 52.6 \\
\cline { 2 - 4 } & Undecided & 23 & 14.7 \\
\cline { 2 - 4 } & Strongly Disagree & 14 & 9.0 \\
\cline { 2 - 4 } & Disagree & 22 & 14.1 \\
\cline { 2 - 4 } & Total & 156 & 100.0 \\
\hline
\end{tabular}


Table 2. Good Structures in place

\begin{tabular}{|l|l|r|r|}
\hline & Frequency & Percent \\
\hline \multirow{2}{*}{ Strongly Agree } & 23 & 14.7 \\
\cline { 2 - 4 } & Agree & 74 & 47.4 \\
\cline { 2 - 4 } & Undecided & 18 & 11.5 \\
\cline { 2 - 4 } & Strongly Disagree & 23 & 14.7 \\
\cline { 2 - 4 } & Disagree & 18 & 11.5 \\
\cline { 2 - 4 } & Total & 156 & 100.0 \\
\hline
\end{tabular}

Table 3. Appreciate the direction of the University in its DE programme

\begin{tabular}{|l|l|r|r|}
\hline & & Frequency & \multicolumn{1}{|c|}{ Percent } \\
\hline \multirow{2}{*}{ Strongly Agree } & 29 & 15.6 \\
\cline { 2 - 4 } & Agree & 90 & 57.7 \\
\cline { 2 - 4 } & Undecided & 19 & 12.2 \\
\cline { 2 - 4 } & Strongly Disagree & 10 & 6.4 \\
\cline { 2 - 4 } & Disagree & 8 & 5.1 \\
\cline { 2 - 4 } & Total & 156 & 100.0 \\
\hline & & & \\
\hline
\end{tabular}

Table4. Cordial Lecturer/Student Relationship

\begin{tabular}{|l|r|r|}
\hline & Frequency & Percent \\
\hline Strongly Agree & 75 & 48.1 \\
\hline Agree & 71 & 45.5 \\
\hline Undecided & 7 & 4.5 \\
\hline Disagree & 1 & 0.6 \\
\hline Strongly disagree & 2 & 1.3 \\
\hline
\end{tabular}

Table 5. Effective Teaching Delivery

\begin{tabular}{|l|r|r|}
\hline & Frequency & Percent \\
\hline Strongly Agree & 17 & 10.9 \\
\hline Agree & 74 & 47.4 \\
\hline Undecided & 19 & 12.2 \\
\hline Disagree & 14 & 9.0 \\
\hline Strongly disagree & 32 & 20.5 \\
\hline
\end{tabular}


Table 6. Constructive Feedback from Lecturers

\begin{tabular}{|l|r|r|}
\hline & Frequency & Percent \\
\hline Strongly Agree & 24 & 15.4 \\
\hline Agree & 92 & 59.0 \\
\hline Undecided & 28 & 17.9 \\
\hline Disagree & 8 & 5.1 \\
\hline Strongly disagree & 4 & 2.6 \\
\hline
\end{tabular}

Table 7. Lecturers tolerated Students input

\begin{tabular}{|l|r|r|}
\hline & Frequency & Percent \\
\hline Strongly Agree & 39 & 25.0 \\
\hline Agree & 94 & 60.3 \\
\hline Undecided & 17 & 10.9 \\
\hline Disagree & 5 & 3.2 \\
\hline Strongly disagree & 1 & 0.6 \\
\hline
\end{tabular}

Table 8 . Study materials that aid teaching

\begin{tabular}{|l|r|r|}
\hline & Frequency & Percent \\
\hline Strongly Agree & 28 & 17.9 \\
\hline Agree & 64 & 41.1 \\
\hline Undecided & 28 & 17.9 \\
\hline Disagree & 16 & 10.3 \\
\hline Strongly disagree & 20 & 12.8 \\
\hline
\end{tabular}

\section{FINANCIAL}

Table 9. Reasonable fee structure for the DE programme

\begin{tabular}{|l|r|r|}
\hline & Frequency & Percent \\
\hline Strongly Agree & 13 & 8.3 \\
\hline Agree & 51 & 32.7 \\
\hline Undecided & 21 & 13.5 \\
\hline Strongly Disagree & 44 & 28.2 \\
\hline Disagree & 27 & 17.3 \\
\hline Total & 156 & 100.0 \\
\hline
\end{tabular}


Table 10. Reasonable fee payment structure/arrangement in place for students

\begin{tabular}{|r|l|r|r|}
\hline & & Frequency & Percent \\
\hline Valid & Strongly Agree & 12 & 7.7 \\
\cline { 2 - 4 } & Agree & 69 & 44.2 \\
\cline { 2 - 4 } & Undecided & 22 & 14.1 \\
\cline { 2 - 4 } & Strongly Disagree & 34 & 21.8 \\
\cline { 2 - 4 } & Disagree & 19 & 12.2 \\
\cline { 2 - 4 } & Total & & 100.0 \\
\hline
\end{tabular}

Table 11. Reasonable cost structure for academic materials

\begin{tabular}{|l|r|r|}
\hline & Frequency & Percent \\
\hline Strongly Agree & 5 & 3.2 \\
\hline Agree & 64 & 41.0 \\
\hline Undecided & 38 & 24.4 \\
\hline Strongly Disagree & 29 & 18.6 \\
\hline Disagree & 20 & 12.8 \\
\hline Total & 156 & 100.0 \\
\hline
\end{tabular}

\section{PSYCHOLOGICAL}

Table 12. Conducive academic atmosphere in support to students learning

\begin{tabular}{|r|l|r|r|}
\hline & & Frequency & Percent \\
\hline \multirow{3}{*}{ Valid } & Strongly Agree & 29 & 18.6 \\
\cline { 2 - 4 } & Agree & 77 & 49.4 \\
\cline { 2 - 4 } & Undecided & 16 & 10.3 \\
\cline { 2 - 4 } & Strongly Disagree & 17 & 10.9 \\
\cline { 2 - 4 } & Disagree & 17 & 10.9 \\
\cline { 2 - 4 } & Total & 156 & 100.0 \\
\hline
\end{tabular}

Table 13. Effective counseling unit in place in support of students' non-academic and psychological issues

\begin{tabular}{|l|r|r|}
\hline & Frequency & Percent \\
\hline Strongly Agree & 7 & 4.5 \\
\hline Agree & 21 & 13.5 \\
\hline Undecided & 36 & 23.0 \\
\hline Strongly Disagree & 55 & 35.3 \\
\hline Disagree & 37 & 23.7 \\
\hline Total & 156 & 100.0 \\
\hline
\end{tabular}


Table 14. Available avenues for students to report their concerns with regards to their academic work

\begin{tabular}{|r|l|r|r|}
\hline & & Frequency & Percent \\
\hline \multirow{3}{*}{ Valid } & Strongly Agree & 17 & 10.9 \\
\cline { 2 - 4 } & Agree & 63 & 40.4 \\
\cline { 2 - 4 } & Undecided & 22 & 14.1 \\
\cline { 2 - 4 } & Strongly Disagree & 31 & 19.9 \\
\cline { 2 - 4 } & Disagree & 23 & 14.7 \\
\cline { 2 - 4 } & Total & 156 & 100.0 \\
\hline
\end{tabular}

Table 15. Effective counseling unit in place to support students' academic work

\begin{tabular}{|l|r|r|}
\hline & Frequency & Percent \\
\hline Strongly Agree & 11 & 7.1 \\
\hline Agree & 21 & 13.5 \\
\hline Undecided & 32 & 20.5 \\
\hline Strongly Disagree & 62 & 39.7 \\
\hline Disagree & 30 & 19.2 \\
\hline & 156 & 100.0 \\
\hline Total & & \\
\hline
\end{tabular}

\section{SOCIAL PROBLEMS}

Table 16. Satisfied with informal support/social support from mates

\begin{tabular}{|l|l|r|r|}
\hline & & Frequency & Percent \\
\hline \multirow{3}{*}{ Valid } & Strongly Agree & 19 & 12.2 \\
\cline { 2 - 4 } & Agree & 79 & 50.5 \\
\cline { 2 - 4 } & Undecided & 35 & 22.4 \\
\cline { 2 - 4 } & Strongly Disagree & 14 & 9.0 \\
\cline { 2 - 4 } & Disagree & 9 & 5.8 \\
\cline { 2 - 4 } & Total & 156 & 100.0 \\
\hline
\end{tabular}

Table 17. Satisfied with support from significant others at home

\begin{tabular}{|l|r|r|}
\hline & Frequency & Percent \\
\hline Strongly Agree & 16 & 10.3 \\
\hline Agree & 67 & 42.9 \\
\hline Undecided & 36 & 23.1 \\
\hline Strongly Disagree & 17 & 10.9 \\
\hline Disagree & 20 & 12.8 \\
\hline Total & 156 & 100.0 \\
\hline
\end{tabular}


Table 18. Support from home 2014, Vol. 1, No. 2

\begin{tabular}{|l|r|r|}
\hline & Frequency & Percent \\
\hline Strongly Agree & 23 & 14.7 \\
\hline Agree & 71 & 45.5 \\
\hline Undecided & 23 & 14.7 \\
\hline Disagree & 20 & 12.9 \\
\hline Strongly disagree & 19 & 12.2 \\
\hline
\end{tabular}

\section{Copyright Disclaimer}

Copyright reserved by the author(s).

This article is an open-access article distributed under the terms and conditions of the Creative Commons Attribution license (http://creativecommons.org/licenses/by/3.0/). 